\title{
EFFECT OF THE $\mathrm{AL}_{2} \mathrm{O}_{3}$ PARTICLE ON THE WEAR RATE AND MICROSTRUCTURE OF HYPO AND HYPER AL-SI ALLOYS
}

${ }^{*}$ Lara A. Ali ${ }^{1}$

\author{
Zeyad D. Kadhim 1
}

1) Department of materials engineering, college of engineering, Mustansiriyah University, Baghdad, Iraq.

\begin{abstract}
In the present work wear performance and hardness of as cast Al-Si alloys before and after the addition of $\mathrm{Al}_{2} \mathrm{O}_{3}$ were investigated. Wear specimens of cylindrical shape were prepared from cast ingot. Wear test were conducted on the samples by using pin on dick wear type. The test variable were load and time. It was observed that when Silicon content increased the hardness increased while the wear rate decreased. When the load and time increased the wear rate also increased. By the addition of $\mathrm{Al} 2 \mathrm{O} 3$ particles the wear rate decreased while the hardness increased
\end{abstract}

Keywords: Aluminum silicon alloy; wear; hardness; $\mathrm{Al}_{2} \mathrm{O}_{3}$

\section{Introduction}

Universal attempt to decrees emissions of dangerous exhaust, coast reducing and improve fuel of vehicle, so aluminum alloys is the best choice because of their lightweight they used in piston, bearing etc [1]. Aluminum silicon composite consist from two or more materials the purpose of composite is to give the material the desired properties[2]. Depending on silicon percentage aluminum silicon alloy divided into three main group: first group if silicon content between $5 \%$ and $10 \%$ the alloy was called hypoeutectic, second group if silicon content between $11.5-12 \%$ the alloy called eutectic, third group if silicon content between $14 \%-20 \%$ the alloy called hypereutectic [3]. Aluminum silicon casting widely used in industrial because their premium mechanical properties, corrosion resistance and good casting properties [4] , they were used in marine application, aerospace, etc. [5]. The properties of aluminum silicon alloys were influenced by silicon particles distribution and shape [6]. The strength of aluminum silicon alloys increased when silicon content decreased but the hardness of these alloys will decreased [7, 8] . Also the silicon addition result in increased wear resistance of aluminum silicon alloys [9]. When the surface of aluminum silicon alloy was loaded and subjected to sliding motion wear was occurred. Wear result in substance loss from the surface of materials [10]. The strength of aluminum matrix composite increased by reinforcement by $\mathrm{Al}_{2} \mathrm{O}_{3}, \mathrm{~B}_{4} \mathrm{C}$ and $\mathrm{SiC}$ etc. this additive result in wear enhancement and increase ratio of weight to strength $[11,12]$.Stir casting method was widely used to produce aluminum silicon composite alloy [13]. In this process the metal melted in furnace then vortex was formed by stirring the metal. Oxide formation is prohibit

*Corresponding Author: lara.eng780@gmail.com 
By adding inert gas. When particles were added string stopped. Then the molten poured in die. Speed of stirring, time of stirring, melt temperature and mold temperature are critical parameters in stir casting process.

In the present work aluminum silicon alloy reinforced by addition the $\mathrm{Al}_{2} \mathrm{O}_{3}$ particles by using stir casting method and study the effect of these additive on the wear performance, hardness and microstructure of aluminum silicon alloy.

\section{Experimental work}

\subsection{Preparation of aluminum - silicon alloy}

Aluminum silicon alloy with chemical composition that shown in "Table 1". Was prepared for this work by used metal mold casting. This process was done by place Al wires in clay bonded graphite crucible, and after that, this crucible will be put in a gas furnace to the point of aluminum melting. Then Fe and cu were added to Al molt and mixing with molten. . After that, the pure Si of the commercial bulk will be added and mixed with the use of the graphite mixer to the point where all quantities of the $\mathrm{Si}$ will be dissolved in molten of $\mathrm{Al}$. Then $\mathrm{Mg}$ and $\mathrm{Zn}$ will be added as well into the molten and mixed. Afterwards, slag remover aqueous aluminum chloride add to the molten of $\mathrm{Al}$ in the ratio of 1 gram. And after that, the slag was removed from the molten. The cast iron mold pre heated at the temperature of $200{ }^{0} \mathrm{C}$ and the molten was poured inside the mold. The poured process is re held with different silicon percentage. Cast rod was obtained with diameter of $14 \mathrm{~mm}$ and length of $22 \mathrm{~cm}$. The homogenous process was held to cast rod through the placing of cast rod into the electrical furnace at a $500{ }^{0} \mathrm{C}$ temperature for five hours and left them to cool in a furnace air for the purpose of obtaining homogenous grain.
After obtaining alloys with two different concentrations of silicon, the plumbing process was carried out again and with the same work steps mentioned above where $\mathrm{Al}_{2} \mathrm{O}_{3}$ added at a concentration of $7 \%$ by stir casting Technique, knowing that the material was wrapped in aluminum foil and heated to a temperature of $200^{\circ} \mathrm{C}$ to get rid of moisture before putting it to the molten.

\subsection{The Microstructure test}

The alloys were prepared for microstructure test by cut these with length $1 \cdot \mathrm{mm}$, and samples grinding by using emery papers with different grade $(220,400,600,800,1000,1200,1500$, and 2000). Water was used as coolant to avoid heat rising. The specimens was polished by using alumina. The samples washed by using water and alcohol and dried by using air. Then (99.5 water and $0.5 \mathrm{HF}$ ) used as etching solution.

\subsection{The Hardness test}

Vickers hardness test was utilized in the present work to measure the hardness of samples. By using load of $1 \mathrm{~kg}$ for $15 \mathrm{sec}$. then the penetration diagonal was calculated by using equation (1).

$$
\mathrm{H} . \mathrm{V}=1.854 \times \mathrm{P} / \mathrm{d}(\mathrm{Av})^{2}
$$

Where HV: Vickers hardness

$$
\begin{aligned}
& \text { P: load } \\
& d_{(A V)} \text { : penetration diagonal }
\end{aligned}
$$

\subsection{The Wear test}

For wear messurment pin on disck device was utilized in the present work. The samples were cut in the length of $30 \mathrm{~mm}$ and diameter of 10 $\mathrm{mm}$. in the present work two loads were utilized $(5$ and $10 \mathrm{~N})$ and sliding volicty of $(490 \mathrm{~m} / \mathrm{s})$ at different time $(5,10,15$ and $20 \mathrm{~min})$.

The wear rate of the samples were calculated according to eqution (2)

Wear rate (w.r) $=\Delta w / \pi \mathrm{DNt}$ 
Where $\Delta w: \mathrm{W}_{0}-\mathrm{W}_{1}$

D: sliding distance $(14 \mathrm{~cm})$

$$
\begin{aligned}
& \mathrm{t}=\text { time }(\min ) \\
& \mathrm{N}=\operatorname{velocity}(\mathrm{rpm})
\end{aligned}
$$

Table 1. The chemical composition of Al-Si alloys

\begin{tabular}{lccccccccccc}
\hline element & $\mathrm{Si} \%$ & $\mathrm{Fe} \%$ & $\mathrm{Cu} \%$ & $\mathrm{Mn} \%$ & $\mathrm{Mg} \%$ & $\mathrm{Cr} \%$ & $\mathrm{Ni} \%$ & $\mathrm{Zn} \%$ & $\mathrm{Ti} \%$ & $\mathrm{~Pb} \%$ & $\mathrm{Al} \%$ \\
Sample1 & 5.7 & 0.546 & 3.45 & 0.0310 & 0.404 & 0.0227 & 0.054 & 0.50 & 0.0291 & 0.0063 & Bal \\
Sample2 & 13.11 & 0.811 & 2.35 & 0.0827 & 0.603 & 0.011 & 0.031 & 0.720 & 0.058 & 0.003 & Bal \\
\hline
\end{tabular}

\section{Results and dissuction}

\subsection{Effect of $\mathrm{Al}_{2} \mathrm{O}_{3}$ and $\mathrm{Si}$ additions on the microstructure of AL-Si alloy}

"Fig. 1", show the microstructre of Al-Si alloy, Figure $a$ and $b$ show the microstructre of alloy with different precentage of Si. The microstructure relive that alpha aluminum and $\mathrm{Si}$ etuctic. When the precentage of sillicon increased rod of si eutectic will increasing and plate of Si appearance as shown in figure $\mathrm{b}$. after the addition of $\mathrm{Al}_{2} \mathrm{O}_{3}$ it was shown that the microstructer become more refined and become more homogenous as shown in $\mathrm{c}$ and $\mathrm{d}$.

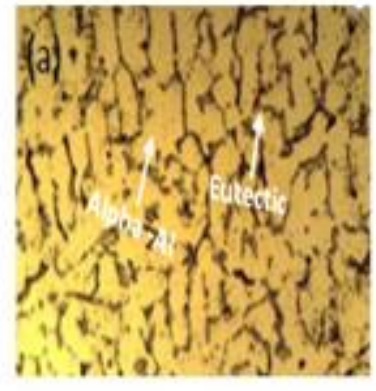

(a)

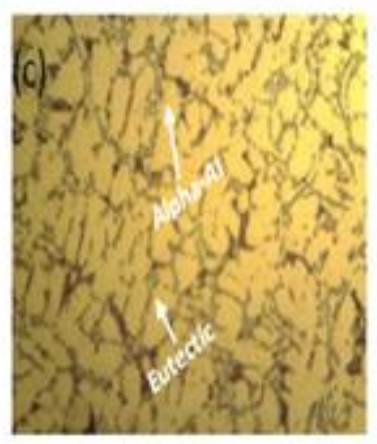

(c)

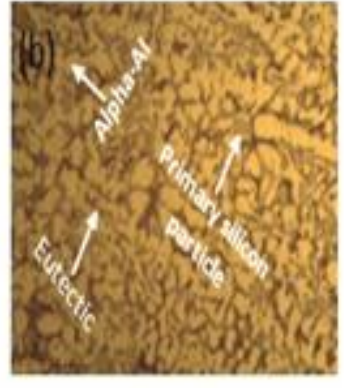

(b)

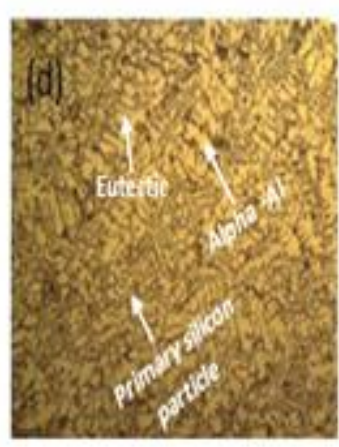

(d)
Figure 1. the microstructre of Al-Si alloys before and after the adding of $7 \%$ alumina: a) Al-5\% Si alloy ; b) Al-13\% Si alloy ; c) Al-5\%Si after addition alumina ; d) Al-13\% Si after addition alumina .

\subsection{XRD test results}

It was obsserived that from the XRD test befor the addition of $\mathrm{Al}_{2} \mathrm{O}_{3}$, the major peaks were $\mathrm{Al}$ and $\mathrm{Si}$, and the mainor peakes are $\mathrm{Al}_{2} \mathrm{Cu}$ and $\mathrm{Al}_{3.21} \mathrm{Si}_{0.47}$. 


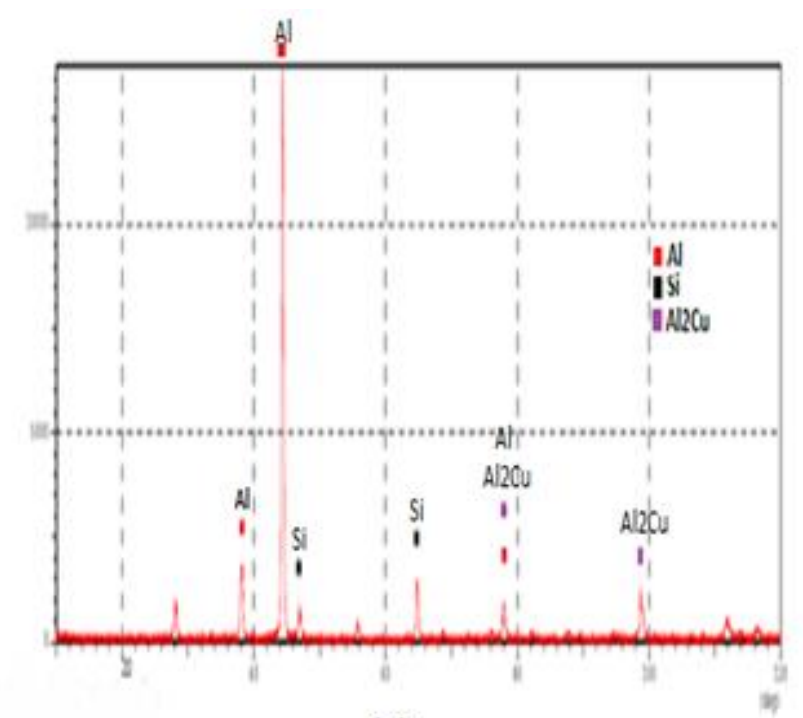

(a)

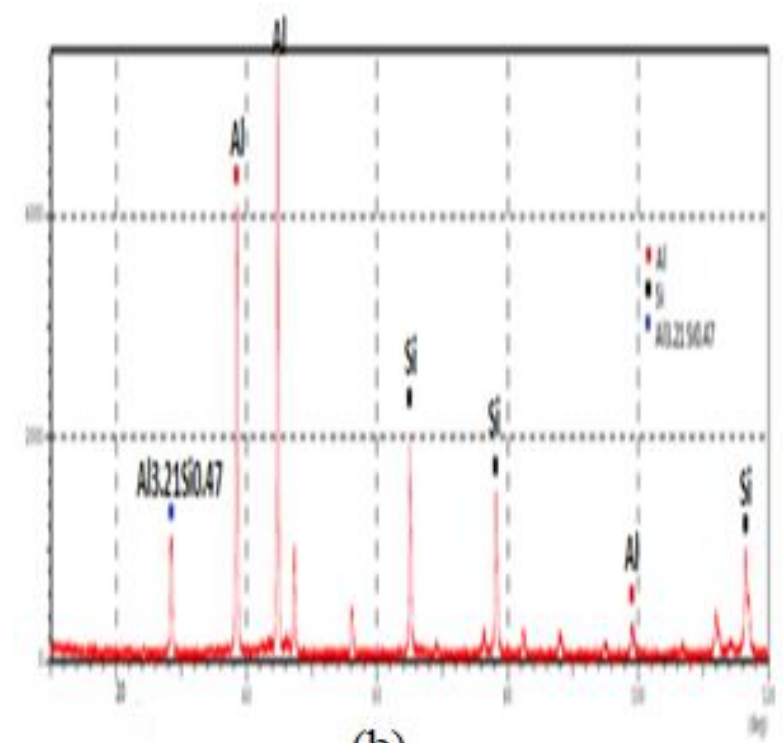

(b)

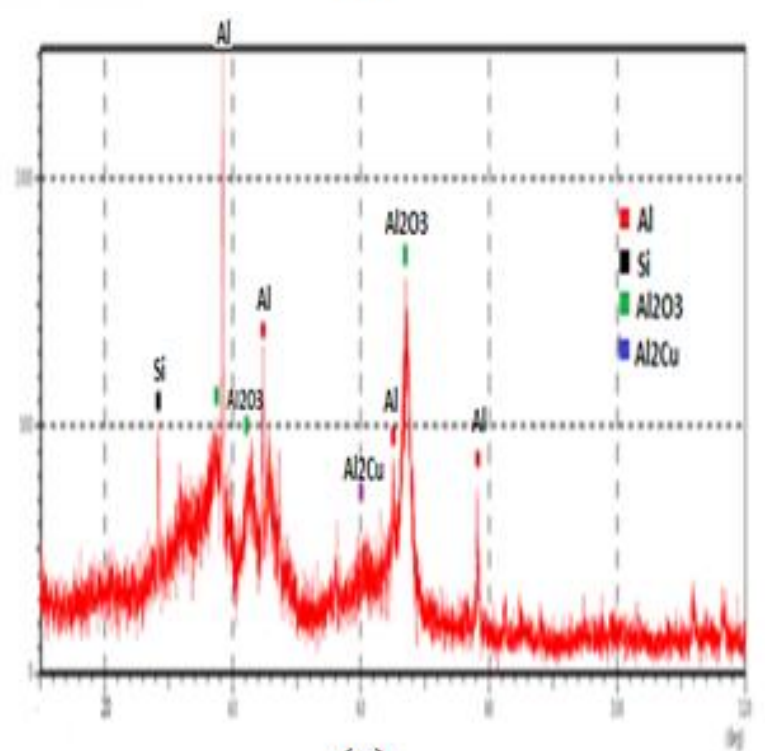

(c)

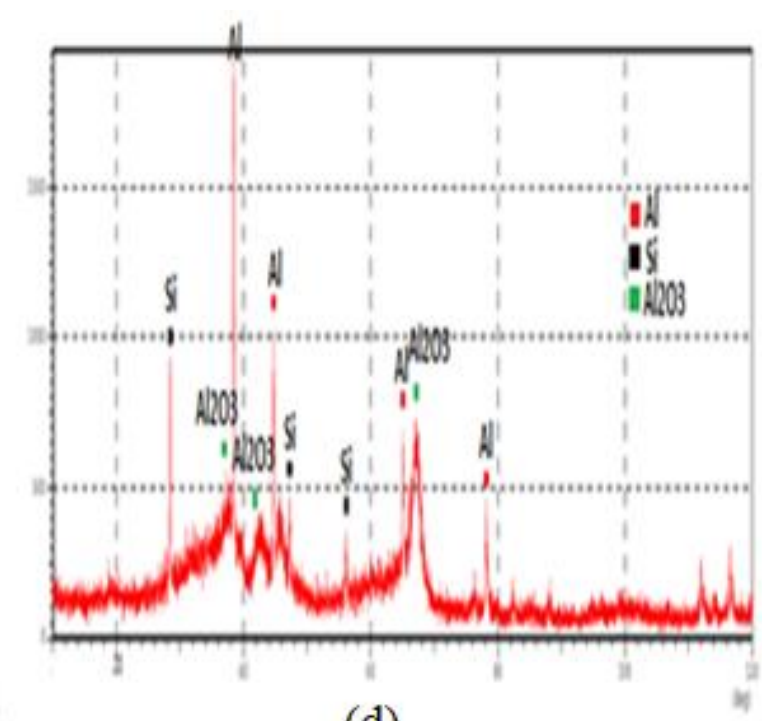

(d)

Figure 2.the XRD analysis of aluminum silicon alloy; a) Al with $5 \%$ of Silicon , b) Al with $13 \%$ of Silicon , c) $\mathrm{Al}$ with $5 \%$ of Silicon after addition alumina , d) Al with $13 \%$ of Silicon after addition alumina .

Table 2. the intensities (I) and the angle of diffraction

\begin{tabular}{cccc}
\hline Alloy & Phase & $2 \theta$ & $\mathrm{I} / \mathrm{I} 1$ \\
$\mathrm{Al}-$ & $\mathrm{Al}$ & $44.35,38.12,77.94$ & $100,13,7$ \\
$5 \% \mathrm{Si}$ & & & \\
$\mathrm{Al}-$ & $\mathrm{Si}$ & $64.76,46.94$ & 11,5 \\
$5 \% \mathrm{Si}$ & & & \\
$\mathrm{Al}-$ & $\mathrm{Al}{ }_{2} \mathrm{Cu}$ & $77.97,98.75$ & 7,10 \\
$5 \% \mathrm{Si}$ & & & \\
$\mathrm{Al}-$ & $\mathrm{Al}$ & $44.76,38.51,99.08$ & $100,76,6$ \\
$13 \% \mathrm{Si}$ & & & \\
$\mathrm{Al}-$ & $\mathrm{Si}$ & $65.04,78.22,116.50$ & $39,34,22$ \\
$13 \% \mathrm{Si}$ & & & 19 \\
$\mathrm{Al}-$ & $\mathrm{Al} .21$ & 28.44 & \\
$13 \% \mathrm{Si}$ & $\mathrm{Si} 0.47$ & & \\
\hline
\end{tabular}


Table 3. the intensities (I) and the angle of diffraction after the addition of $\mathrm{AL}_{2} \mathrm{O}_{3}$

\begin{tabular}{|c|c|c|c|}
\hline Alloy & phase & 2Theta & $\mathrm{I} / \mathrm{I} 1$ \\
\hline $\begin{array}{c}\mathrm{Al}- \\
5 \% \mathrm{Si}\end{array}$ & $\mathrm{Al}$ & $38.4,66.9,44.6,78.1$ & $100,49,44,38$ \\
\hline $\begin{array}{c}\mathrm{Al}- \\
5 \% \mathrm{Si}\end{array}$ & $\mathrm{Si}$ & 28.7 & 8 \\
\hline $\begin{array}{c}\mathrm{Al}- \\
5 \% \mathrm{Si}\end{array}$ & $\mathrm{Al} 2 \mathrm{Cu}$ & 60.2 & 6 \\
\hline $\begin{array}{c}\mathrm{Al}- \\
5 \% \mathrm{Si}\end{array}$ & $\mathrm{Al} 2 \mathrm{O} 3$ & $67.2,42 \cdot 2,37.4$ & $59,16,10$ \\
\hline $\begin{array}{c}\text { Al- } \\
13 \% \mathrm{Si}\end{array}$ & $\mathrm{Al}$ & $38.4,44.7,65.78 .1$ & $100,42,29,24$ \\
\hline $\begin{array}{c}\text { Al- } \\
13 \% \mathrm{Si}\end{array}$ & $\mathrm{Si}$ & $28.4,47.2,58.1$ & $43,16,3$ \\
\hline $\begin{array}{c}\text { Al- } \\
13 \% \mathrm{Si}\end{array}$ & $\mathrm{A} 12 \mathrm{O} 3$ & $67.1,42 \cdot 5,37.6$ & $22,7,5$ \\
\hline
\end{tabular}

\subsection{Hardness test Results}

As shown in the "Table 4", the hardness of ALSi alloy increased when the percentage of silicon was increased, due to plate of $\mathrm{Si}$ precipitation during the solidification process, and this can be attributed to the presence of fine intermetallic compound such as aluminum silicon (Al3.21Si0.47). When $\mathrm{Al}_{2} \mathrm{O}_{3}$ was added, the hardness also increased because $\mathrm{Al}_{2} \mathrm{O}_{3}$ act as barriers for alloy distortion due to, their high hardness. Also it act as barriers for dislocation movement.

Tabel 4. vicker Hardness $\left(\mathrm{kg} / \mathrm{mm}^{2}\right)$ for alloy befor and after addition $\mathrm{Al}_{2} \mathrm{O}_{3}$.

\begin{tabular}{ccc}
\hline Alloy & As received & $\begin{array}{c}\text { After addition } \\
\mathrm{Al} 2 \mathrm{O} 3\end{array}$ \\
$\mathrm{Al}-5 \% \mathrm{Si}$ & 47 & 59 \\
$\mathrm{Al}-13 \% \mathrm{Si}$ & 65 & 78 \\
\hline
\end{tabular}

\subsection{Wear test results}

"Fig. 3" and "Fig. 4", show the relesheionship between the wear rate and time at different load for AL-Si alloys before and after the addition of $\mathrm{Al}_{2} \mathrm{O}_{3}$. it was shown that wear rate increase as result of sliding reaction that occur between the two sliping metal surface [14]. It also observed that when the silicon content increased the hardness increased so the wear rate will decrease due to praimmery silicon particals and fine intermetallic compound (Al3.21Si0.47) may be result in deceased rate of wear . at low values of the load wear lost which are discovered as fine particles and protective oxide layer will be formed, and the area of the contact between the disc and the samples will be decreased, which is why, wear rate will be decreased. While at load of $10 \mathrm{~N}$ sever wear will occur. in this load wear lost found in the form of large metallic particals. The oxide layer will break out thus result in increased wear rate. The contact area between the burrs will increased. This burrs will break out and Separate from the surface..When the load increased the silicon particals will Break up and the break silicon will become spheriodis as result of high temperature that occur between the two sliping surface. After the addition of ceramic particles, $\left(\mathrm{Al}_{2} \mathrm{O}_{3}\right)$ phase were appeared and this will result in increase the wear resistance .

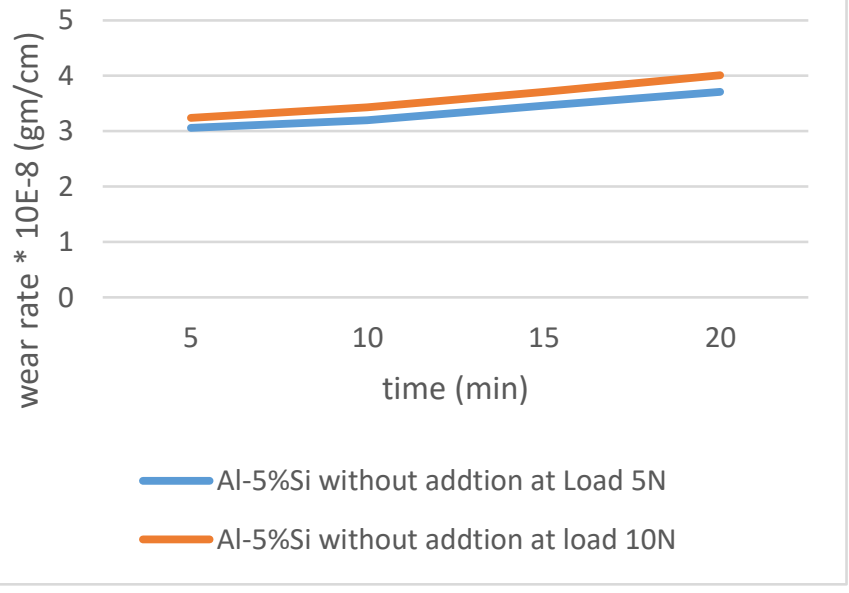

(a) 


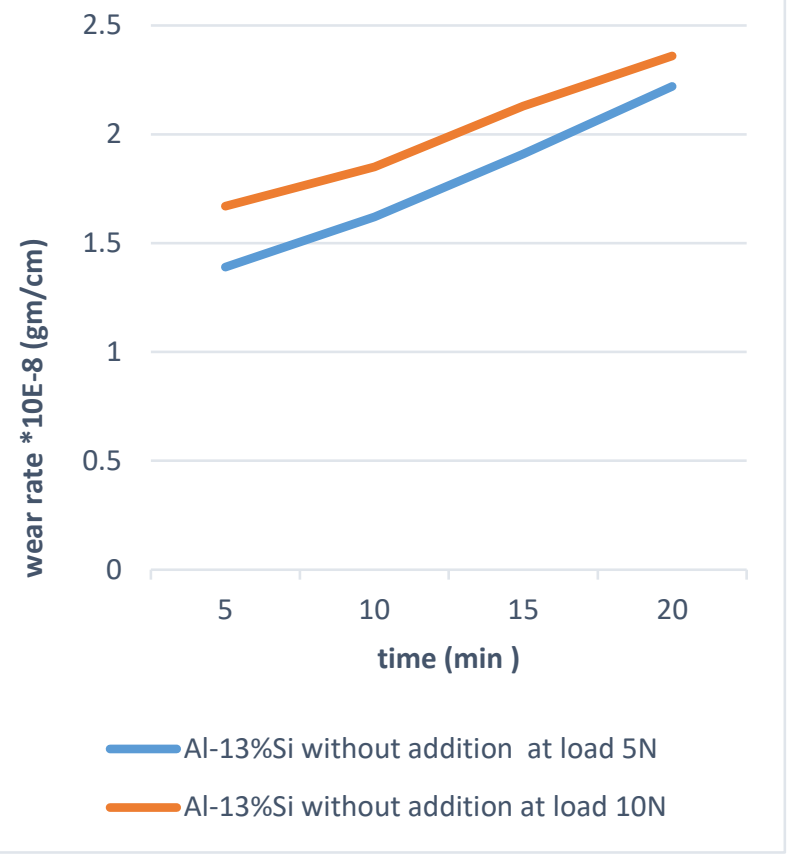

(b)

Figure 3. the wear rate of Al-Si alloy before the addition of $\mathrm{Al}_{2} \mathrm{O}_{3}$; a) $\mathrm{Al}-5 \% \mathrm{Si}$ alloy ; b) $\mathrm{Al}-13 \%$ Si alloy

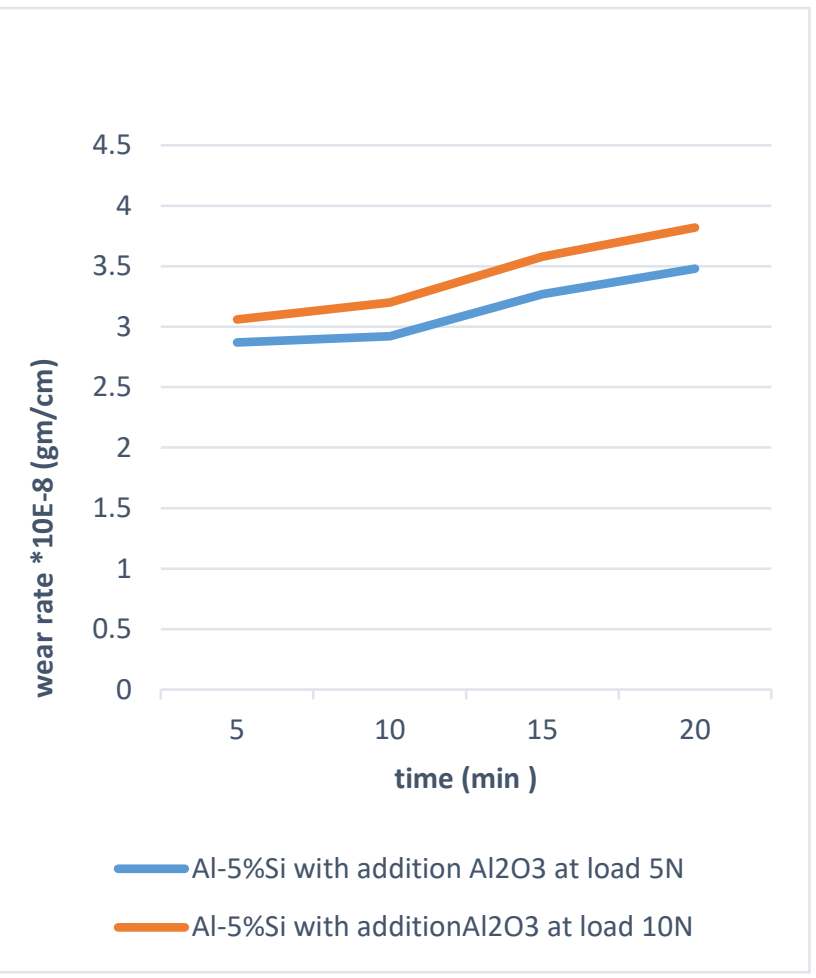

(a)

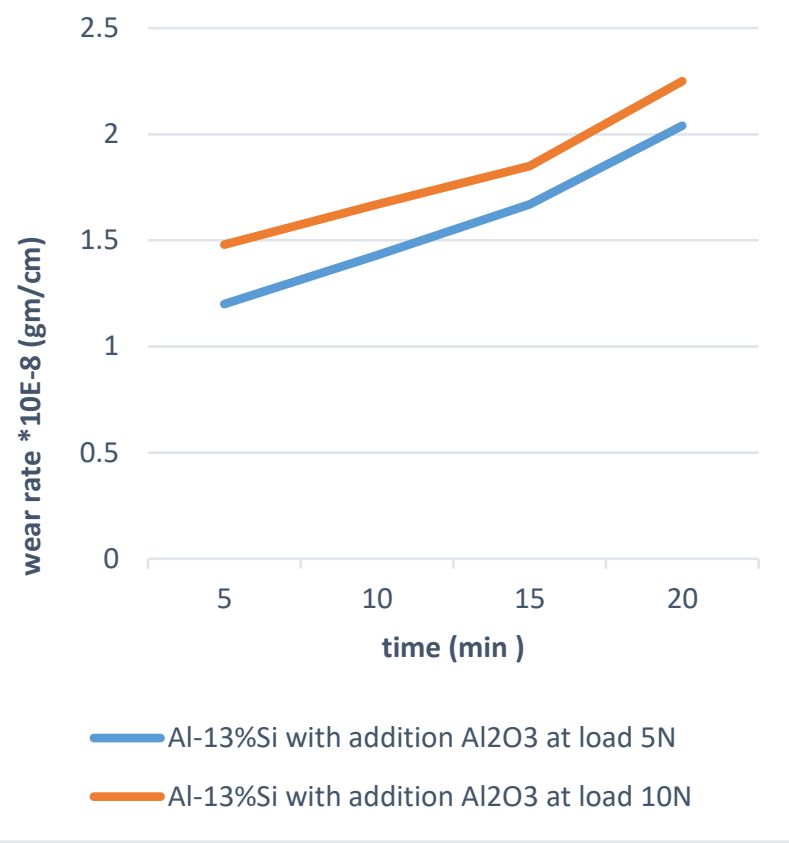

(b)

Figure 4. the wear rate of $\mathrm{Al}-\mathrm{Si}$ alloy after the addition of $\mathrm{Al}_{2} \mathrm{O}_{3}$; a) $\mathrm{Al}-5 \% \mathrm{Si}$ alloy with addition $\mathrm{Al}_{2} \mathrm{O}_{3}$;b)Al-13\% Si alloy with addition $\mathrm{Al}_{2} \mathrm{O}_{3}$.

\section{Conclutions}

1- Hardness increased by the increased in $\mathrm{Si}$ content from (47-65) HV.

2- When added alumina, the hardness value in Al-5\% Si alloy increased from (47-59) HV, and in Al-13\%Si alloy increased from (6578) $\mathrm{HV}$.

3- When Si content increased the wear rate decreased.

4- The wear rate of $\mathrm{Al}-5 \% \mathrm{Si}$ increased from $\left(3.06^{*} 10^{-8}-3.71 * 10^{-8}\right)$ at load $5 \mathrm{~N}$ and at load $10 \mathrm{~N}$ increased from $\left(3.24 * 10^{-8}\right.$ $\left.4.06^{*} 10^{-8}\right)$, in $\mathrm{Al}-13 \% \mathrm{Si}$ wear rate increased from $\left(1.39 * 10^{-8}-2.22 * 10^{-8}\right) \mathrm{gm} / \mathrm{cm}$ at load $5 \mathrm{~N}$ and increased from $\left(1.67 * 10^{-8}-2.36 * 10^{-}\right.$ ${ }^{8}$ ) $\mathrm{gm} / \mathrm{cm}$ at load $10 \mathrm{~N}$.

5- The addition of alumina to the alloy lead to wear rate decreased. 


\section{Acknowledgements}

The authors would be like to thank the staff of Mustansiriya University (www.upomustansiriyah.edu.iq) Bagdad-Iraq, for their support in the present work.

\section{Conflict of interest}

The author confirm that there's no conflict of interest.

\section{Abbreviations}

$\begin{array}{ll}\mathrm{Al} & \text { aluminum } \\ \mathrm{Si} & \text { silicon } \\ \mathrm{Al}_{2} \mathrm{O}_{3} & \text { alumina } \\ \mathrm{Fe} & \text { iron } \\ \mathrm{Cu} & \text { copper } \\ \mathrm{Zn} & \text { zinc } \\ \mathrm{Mg} & \text { Magnesium } \\ \mathrm{B}_{4} \mathrm{C} & \text { Boron carbide }\end{array}$

\section{References}

1. Al-Samarai, A.R.A., K.R.A. Haftirman, and Y. Al-Douri, (2013). Effect of roughness of hypo-and hyper-eutectic Al-Si piston alloy on wear characteristics under lubrication. Procedia Engineering, Vol. 53, pp. 616-623.

2. Saheb, D.A., (2011). Aluminum silicon carbide and aluminum graphite particulate composites. ARPN Journal of Engineering and Applied Sciences, Vol. 6, No.10, pp. 4146.

3. Ammar, H., A. Samuel, and F. Samuel, (2008). Porosity and the fatigue behavior of hypoeutectic and hypereutectic aluminumsilicon casting alloys. International journal of Fatigue, Vol.30, No.6, pp. 1024-1035.

4. Ravi, B., B.B. Naik, and J.U. Prakash, (2015). Characterization of aluminium matrix composites (AA6061/B4C) fabricated by stir casting technique. Materials Today: Proceedings, Vol. 2, No. ${ }^{\circ} \_$, pp. 2984-2990.

5. Dwivedi, D., (2010). Adhesive wear behavior of cast aluminium-silicon alloys: Overview. Materials \& Design (1980-2015), Vol.31, No.5, pp. 2517-2531.

6. Ozioko, F.U., (2012). Synthesis and study on effect of parameters on dry sliding wear characteristics of Al-Si alloys. Leonardo Electronic Journal of Practices and Technologies, Vol. 20, pp. 39-48.

7. Çetin, M., (2019). Abrasive wear behaviour of cast $\mathrm{Al}-\mathrm{Si}-\mathrm{Mn}$ alloys. Proceedings of the Institution of Mechanical Engineers, Part E, Journal of Process Mechanical Engineering. Vol.233, No.4, pp. 908-918.

8. Saravanan, R. And R. Sellamuthu, (2014). An investigation of the effect of surface refining on the hardness and the wear properties of AlSi alloy. Applied Mechanics and Materials. Vol. 592, pp 53-57.

9. Dey, S r.T. Perry, and A. Alpas, (2009). Micromechanisms of low load wear in an $\mathrm{Al}$ 18.5\% Si alloy. Wear, Vol.267, No.1-4, pp. $515-524$

10. Dodiya, V. And J. Parmar, (2016). A study of various wear mechanism and its reduction method. Int J Innovative Res Sci Technol, Vol. 2, pp. 242-248.

11. Ramesh, C., et. al., (2009). Microstructure and mechanical properties of $\mathrm{Ni}-\mathrm{P}$ coated Si3N4 reinforced Al6061 composites. Materials Science and Engineering: A. Vol.502, No.1-2, pp. 99-106.

12. Vencl, A., et al., (2010). Structural, mechanical and tribological properties of A356 aluminium alloy reinforced with Al2O3, $\mathrm{SiC}$ and $\mathrm{SiC}+$ graphite particles. Journal of alloys and compounds. Vol.506, No.2, pp. 631-639.

13. Gopalakrishnan, S. And N. Murugan, (2012). Production and wear characterisation of $A A$ 6061 matrix titanium carbide particulate 
reinforced composite by enhanced stir casting

method. Composites Part B: Engineering.

Vol.43, No.2, pp. 302-308.

14. Yasmin, T., A.A. Khalid, and M. Haque, (2004). Tribological (wear) properties of aluminum-silicon eutectic base alloy under dry sliding condition. Journal of Materials Processing Technology, Vol.153, pp. 833838. 